\title{
Nutritional Status with Infant Motor Development
}

\author{
Nurwinda Saputri ${ }^{1}$, Eriska Prahasti ${ }^{2}$ \\ ${ }^{1,2}$ Prodi DIII Midwifery, STIKes Muhammadiyah Pringsewu, Indonesia \\ ․ㅡurwindasaputri17@gmail.com, ${ }^{2}$ prahastieriska2@gmail.com
}

\begin{abstract}
Keywords:

Nutritional Status, Motor Development, Toddler.

Children under the age of five (toddler) Indonesia experience nerve development and brain disorders ranging from mild to severe. Every 2 out of 1,000 babies experience motor development disorders. Factors affecting motor development in toddlers, such as hereditary, prenatal environment, postnatal environment. Nutritional status plays an important role in motor development. The purpose of this research is to know the relationship of nutritional status with the development of coarse motor toddler This research is an analytical survey research with cross sectional approach. Sampling techniques used are total sampling. Sample as much as 60 toddlers. This data is collected using checklist and observation sheets. Hypothesis test using Chi square correlation analysis. Data analysis results show the value of $\mathrm{P}$ value $(0.000)<\alpha(0.05)$ which means there is a significant relationship as well as the relation of relationships belonging to the strong category with the frequency value of the coefficient of (0.625). In conclusion there is a relationship of nutritional status with the infant motor development, and the relationship of these two variables is significant.
\end{abstract}

\section{Article History:}

Received: $10-10-2018$

Revised : 20-12-2018

Accepted: 28-12-2018

Online : $30-12-2018$

\author{
This is an open access article under the CC-BY-SA license \\ 4 crossref \\ https://doi.org/10.31764/ijeca.v1i3.2108
}

\section{A. INTRODUCTION}

The effect of the child growth process is intrinsic and extrinsic factor, e.g. on height which is a function between eating habits, child nutrition fulfilled genetic. Deviation of growth in children may occur if there is interference during the process from intra uterine to adulthood. These deviations can provide clinical manifestations of either abnormalities in growth with or without developmental abnormalities, the clinic manifestation caused by developmental disorders is a rough motion disorder in infants. (Adriana, 2011).

Child development includes physical, cognitive, emotional, language, motor (crude and delicate), social and adaptive personal. Child development monitoring is useful to find developmental irregularities/barriers early in the child, so that prevention efforts, stimulation efforts and healing efforts and recovery efforts can be provided with clear indications as early as possible at critical times of child growth. One of the factors affecting toddler motor development is the postnatal environmental factor, one of which is the nutritional status. Nutritional Status plays an important role in motor development. (Ranuh, 2003).

Nutritional problems in infants is a health disorder caused by the imbalance of fulfillment of the need for nutrients that are obtained from food (Sigit, 2012). There is a tendency to increase 


\section{2 | IJECA (International Journal of Education and Curriculum Application)}

Vol. 1, No. 3, December 2018, pp. 1-4

prevalence in the following years. The high prevalence of poor and malnourished nutrition in infants, also affects the development of rough and delicate motor nervous disorders in infants.

The effect of child growth process is intrinsic and extrinsic factors, e.g. on a height that is a function between eating habits, child nutrition fulfilled genetic. Deviation of growth in children may occur if there is interference during the process from intra uterine to adulthood. These deviations can provide clinical manifestations of either abnormalities in growth with or without developmental abnormalities, the clinic manifestation caused by developmental disorders is a rough motion disorder in infants. (Adriana, 2011). Infancy and children are the times when they experience a period of rapid growth and development, which is very important, which is then the foundation that determines the quality of the nation's successors. Children's critical period is from 6 to 24 months, because age group is a period of critical growth and growth failure starts to be seen.

\section{B. METHODS}

Research using analytical survey research methods (Arikunto, 2010), research draft used is cross sectional (Priyo, 2018) this research will look for relationship of nutritional Status with crude motor development in toddlers. The population of all infants in the Posyandu of Matahari I, samples taken as much as 60 toddlers. Sampling is done by the total sampling technique. This research was conducted in the Posyandu Matahari I, Kediri village, Gadingrejo District (Pringsewu Lampung District).

\section{RESULT AND DISCUSSION}

\section{Univariat Analysis}

Table 1. Frequency distribution of toddler nutrition Status

\begin{tabular}{ccc}
\hline Nutritional Status & Frequency & Presentation (\%) \\
\hline Good & 26 & $43,3 \%$ \\
Less & 34 & $56,7 \%$ \\
Bad & - & $0 \%$ \\
\hline Amount & $\mathbf{6 0}$ & $\mathbf{1 0 0 \%}$ \\
\hline
\end{tabular}

From the Table 1. known frequency distribution based on the nutritional status of toddlers in the Sun Posyandu I Village Kediri District Gading Rejo District Pringsewu Lampung The number of infants with a nutritional status of less than 34 toddlers (56.7\%) And not found toddlers with poor nutritional status.

Table 2. Frequency distribution of rough motor development Disorders Toddler

\begin{tabular}{ccc}
\hline Name & Frequency & Presentation (\%) \\
\hline Normal & 28 & $46,7 \%$ \\
Suspects & 32 & $53,3 \%$ \\
\hline Amount & $\mathbf{6 0}$ & $\mathbf{1 0 0 , 0} \%$ \\
\hline
\end{tabular}

From the Table 2. known frequency distribution based on the motor of toddler in Posyandu Matahari I village Kediri Gading Rejo District in 2012 with motor development Status suspect as much as 32 toddlers (53.3\%). 


\section{Bivariat Analysis}

Table 3. Relations of nutritional Status with motor development in infants

\begin{tabular}{|c|c|c|c|c|c|c|c|}
\hline \multirow{3}{*}{$\begin{array}{l}\text { Nutritional } \\
\text { Status }\end{array}$} & \multicolumn{4}{|c|}{ Infant Motor Development } & \multirow{2}{*}{\multicolumn{2}{|c|}{ Total }} & \multirow{3}{*}{$\begin{array}{c}P \\
\text { value }\end{array}$} \\
\hline & \multicolumn{2}{|c|}{ Normal } & \multicolumn{2}{|c|}{ Suspects } & & & \\
\hline & $\mathbf{N}$ & $\%$ & $\mathbf{N}$ & $\%$ & $\mathbf{n}$ & $\%$ & \\
\hline Good & 24 & $40 \%$ & 2 & $3,33 \%$ & 26 & $43,33 \%$ & \multirow{4}{*}{0,000} \\
\hline Less & 4 & $6,67 \%$ & 30 & $50 \%$ & 34 & $56,67 \%$ & \\
\hline Bad & 0 & $0 \%$ & 0 & $0 \%$ & 0 & $0 \%$ & \\
\hline Amount & 28 & $46,67 \%$ & 32 & $53,33 \%$ & 60 & $100 \%$ & \\
\hline
\end{tabular}

From Table 3. The frequency shows the results of the nutritional status of either 24 infants $(40 \%)$ With normal motor development, and 2 toddlers (3.33\%) With motor suspect development. Then, there are 4 toddlers (6.67\%) Nutritional status with normal motor, and $30(50 \%)$ Toddlers nutritional status less with motor development suspect. No toddlers are found in poor nutrition status.

The result of analysis of the relationship of nutritional status with the motor development of toddlers in Posyandu Matahari I by using Chi-Square (X2), using a level of infertility of 0.05 when the value of $P$ value of $<$ from 0.05 then the conclusion is a very meaningful relationship between the meticulously (Ho rejected) of sufficient analysis in Get P value is 0.000 meaning $\mathrm{P}$ value < of 0.05 This indicates that Ho was rejected so that it can be concluded that there is a nutritional status relationship with motor development in infants. However, according to the research of Desmika Wanitika Sari et al (Sari et al., 2012) The results showed that $P=0,370$, so the conclusion is no significant relationship between the status of nutrient with coarse motor children aged 1 - 5 years.

Based on table 4.3 can be known among 60 toddlers there are 32 (53.3\%) Toddlers are at the motor development level suspect. Progression is increased ability in structures and functions of the body more complex in a orderly and predictable pattern, as a result of the maturation process

From the results of the study in 60 children there are 26 (43.3\%) Infants with good nutritional status or on the Green Line, and 34 (56.7\%) Infants with less nutritional status or being on a yellow line and not found in infants with poor nutritional status or under the red line. And from 60 toddlers there are 28 (46,7\%) Infants with normal motor development and there are $32(53,3 \%)$ Toddlers with motor development suspect. This is in accordance with the opinion Muhoozi et al. which is one of the causes of rough motor delay of the child, namely the condition of the child malnourished so that the muscles of his body is not well developed and he does not have enough energy to do the activity. (Muhoozi et al., 2016)

This is reinforced by Hidayat's theory (Hidayat, 2008) which mentions that a person has a nutritional status of good or normal then the reflection given is normal growth, the level of development according to age, the body becomes healthy, good appetite and easily selfimposes with the environment. This is in line with the opinion of Sunawang (Sunawang et al., 2009) Nutrition is one of the factors that affect the development of toddlers. Before birth, children depend on the availability of foodstuffs and gastrointestinal abilities. Mariani Gabriela Kasenda et al. said in addition to coarse motor, nutritional status also affects fine motor in infants. (Mariani Gabriela Kasenda, Sisfiani Sarimin, 2015).

From the results of the above discussion can be concluded that there is a link between the status of nutrient with motor development in infants with a strong relationship. This is caused by environmental and economic status is still said in the category of less, so that in 
fulfilling nutritional and nutritional needs in toddlers is less maximal. Then it is advisable for the community to be more aware to anticipate the possibility of a less nutritional status that is potentially to the status of bad nutrition that can cause disruption of motor development in infants. In this research researchers also found constraints so that there are some limitations of research that is time limitation of the researchers because the time of research that has been specified is quite short so that the target is achieved less than optimal, and the cost limitation of the researchers so that researchers make effective means. The downside in this study is using secondary data on nutritional status data, which only sees the weight gain through KMS toddlers only.

\section{CONCLUSION AND SUGGESTIONS}

It was concluded that there was a significant relationship between the status of nutrition and the motor development of toddlers in Posyandu Matahari I, obtained by the result of infant research with a nutritional status of less than 34 toddlers from 60 respondents or $56.7 \%$. Toddlers with a good nutritional status of 26 toddlers from 60 respondents or $43.3 \%$. And Tidan found toddlers with poor nutritional status. Obtained the research results in Posyandu Matahari I toddlers who have experienced developmental disorders as much as 32 toddlers or $53.3 \%$.

The research is expected to become more developed science so as to support or strengthen existing theories, related to the relationship of nutritional status with the motor development of toddlers. To people who are particularly candidates or mothers have the insight and desire to be obedient in their visits, and to the next researcher to make the research wider.

\section{REFERENCES}

Adriana, D. (2011). Tumbuh Kembang dan Terapi Bermain Pada Anak (2nd ed.). Salemba Medika. Arikunto. (2010). Metodelogi Penelitian. Pendekatan Penelitian, 61-84.

Hidayat, A. A. A. (2008). Pengantar Ilmu Kesehatan Anak untuk Pendidikan Kebidanan. Salemba Medika.

Mariani Gabriela Kasenda, Sisfiani Sarimin, F. O. (2015). Hubungan status gizi dengan perkembangan motorik halus pada anak usia prasekolah di tk gmim solafide kelurahan uner kecamatan kawangkoan induk kabupaten minahasa. Ejournal Keperawatan (E-Kp), 3(1), 2-8. https://media.neliti.com/media/publications/111221-ID-hubungan-status-gizi-denganperkembangan.pdf

Muhoozi, G. K. M., Atukunda, P., Mwadime, R., Iversen, P. O., \& Westerberg, A. C. (2016). Nutritional and developmental status among 6- to 8-month-old children in southwestern Uganda: A cross-sectional study. Food and Nutrition Research, 60. https://doi.org/10.3402/fnr.v60.30270

Priyo, L. S. dan S. H. (2018). Statistik Kesehatan (10th ed.). PT. RajaGrafindo Persada.

Ranuh, S. dan G. (2003). Tumbuh Kembang Anak (2nd ed.). EGC.

Sari, D. W., W, E. N., \& Purwanto, S. (2012). Hubungan Antara Status Gizi Dengan Perkembangan Motorik Kasar Anak Usia 1 - 5 Tahun Di Posyandu Buah Hati Ketelan Banjarsari Surakarta. Jurnal Pendidikan Karakter, 157-164.

Sigit. (2012). Keadaan Status Gizi Terhadap Pertumbuhan dan Perkembangan Anak. Lumbung Pustaka $U N Y, 10-40$.

Sunawang, Utomo, B., Hidayat, A., Kusharisupeni, \& Subarkah. (2009). Preventing low birthweight through maternal multiple micronutrient supplementation: A cluster-randomized, controlled trial in Indramayu, West Java. Food and Nutrition Bulletin, 30(4 SUPPL.). https://doi.org/10.1177/15648265090304s403 